\title{
On the Construction Idea of Sponge City
}

\author{
Wuhan Highway Survey and Design Institute, Wuhan 430015, Hubei Province, China
}

\section{Introduction}

In recent years, affected by the socio-economic development, resulting in China's serious environmental problems, affecting the development of the city. At present, many cities are beginning to explore the construction of sponge city, and developed the relevant measures. In order to promote the comprehensive development of the sea city, we must analyze the concept of sponge city construction, analyze the problem from a comprehensive point of view, and promote the construction of sponge city.

First, to achieve comprehensive utilization of rain

\section{(A) Rainwater use process}

When the rainwater collection is carried out, the roof of the building project and the hardened surface runoff can be inflow into the underground concave collection system, and the inflow is allowed to flow into the ground, and then the concave green space can be filled directly from the project area. Into the rainwater pipeline, and with the rainwater sedimentation tank to collect it into the rainwater storage reservoir, to meet the surrounding ecological scenic water demand growth.

In actual operation, if the rainwater regulation is full, you can directly exceed the standard rain into the surrounding municipal pipelines or gardens and other landscape water. Rainwater harvesting ponds are generally used to filter the collected rainwater and can be used directly as urban watering and shrubs to improve water use efficiency and create a high-quality regional water environment.

In short, rainwater is a natural water resource, can sustain the groundwater resources, but also reduce the urban rainwater pipe network drainage pressure, to achieve the reuse of water resources, with a wide range of application significance.

(B) Comprehensive utilization of rainwater system

First, the rainwater purification system. The rainwater purification system is mainly composed of soil diafiltration purification and artificial wetland purification. The soil seepage filter can generally use the soil to realize the water filtration and purification, and can use the empty tube to collect the collected rainwater directly into the pond; Once the rainfall intensity is large, the soil surface water can be stored directly into the primary purification tank. Artificial wetland purification in order to create a good water environment for people, requiring the project to set up artificial wetlands, mainly for two steps. The first step, primary purification, mainly on the soil impermeable rainwater treatment. The second step to re-purification, mainly after the completion of the primary purification of rain and soil after the diafiltration of rainwater treatment, the general secondary treatment after the completion of the rain can be directly discharged into the pool, or storage. Generally in the primary and secondary purification pool installed to enhance the water pump to complete the water cycle operation.

\begin{abstract}
Sponge city is a new type of urban construction, which can play the natural ecological and artificial functions, realize the rainwater runoff, purify and penetrate, and meet the needs of modern urban development, in response to natural disasters and natural environment changes play a significant effect. This paper mainly analyzes the concept of sponge city construction, hoping to provide a reference for relevant researchers.
\end{abstract}

Key words: Sponge city; construction concept; comprehensive development

Published online: 15th July, 2017

Second, rainwater use. After analysis, it is found that the current collection of rain, mainly from the roof collection of water collection, roof greening, ecological regulation pool and artificial wetlands and other operations. Rainwater indirect use can be from the diaper, filter ditch and so will rain into the soil, to achieve conservation of groundwater or recharge to the basement.

The pond is mainly composed of depression, pond and so on. The pond and the depression are mainly maintained at the water level. The bottom of the pond terminates more plants that can be adsorbed and contaminated. The 
water storage function is strong, and the smooth operation of the aquatic ecosystem is maintained, and the ideal visual effect.

The use of transparent bricks to lay the permeability of the ground, reasonable control of the permeability coefficient, and to achieve the return of rain, timely solution to groundwater recharge and other issues, with the protection of groundwater, and can purify groundwater, the effect is better.

Third, the rainwater harvesting system. Road ditch: by the landscape and functional requirements, generally in the square and the road place to set the permeable bricks. As the road square elevation is significantly higher than the green landmark, so the road plaza rainwater can be collected into the surrounding green space, and then to the underground infiltration. One of the parks in the use of permeable bricks and graded gravel for bedding, and graded gravel cushion laying all through the drainage hose, maintaining the stability of the rainwater infiltration.

In practice, due to the road width and location are different, so the filter can be set to the following forms:(1) The main garden road ditch: road width set at 6 meters, to avoid pedestrian pollution more rain, can be combined with green design requirements reasonable I do not know leaking ditch; (2) Hard square pavement. Set the hard square road, can be combined with pavement and ground slope settings, generally 20 meters in the square set diaper ditch; (3) 3 meters wide garden Road: seepage brick road, filter ditch, perforated water collection set; (4) Wooden plank road: the path below the plank set to low-lying green space; (5), the parking lot: the general set parking lot, the requirements will be pulled to set as long asphalt, and according to the actual situation of the layout of the parking area, so that rainwater infiltration here more serious water pollution, to avoid a reasonable combination of soil infiltration perforated pipe to achieve rainwater collection.

Fourth, the rainwater storage system. Artificial lake: the general set of artificial lake mainly from the following aspects of the operation, first of all primary purification, and then carry out secondary purification, and set the pool. The use of rain, you can directly use the lifting system from the pool to obtain, mainly applied to the green vegetation irrigation and flushing, etc., if the overflow of a small amount of rain, you can directly into the municipal rainwater pipe. In the actual design, the conventional water level is generally 10 $\mathrm{cm}$ lower than that of the overflow water outlet. It can be set according to the high water level of the denomination, increase the rainfall storage, and ensure that the rainfall below 50 $\mathrm{mm}$ does not sleep and overflow, improve the filling hydrophilic effect of the lake, the rainy season water storage requirements. Set the artificial lake, you can also configure the aquatic plants in the lake, with the deposition of rain and sediment rich lake landscape role. In addition, in order to ensure that the lake is clear, to avoid deterioration of the lake, you can achieve the lake water treatment, set up in the lake sprinkler irrigation system to meet the water supply, give full play to the role of rainwater.

\section{Second, the focus of sponge city construction analysis}

Combined with the concept of sponge city construction, can be analyzed from the following aspects: First, the regional people's government is the main building. Sponge city mainly to urban people, the need to coordinate the city, township and village, it must be above the city name of the government as the main responsibility, and the establishment of regional groups to achieve a comprehensive distribution of duties. Second, the city's sponge city is the foundation of the building. China is still in the sponge city exploration, and sponge city-related theory, technology, etc. still need to be improved, it must strengthen the pilot to promote the formation of renewable sponge city construction model; Finally, social participation in sponge city to promote the building. Sponge city is closely related to the vital interests of the public, the need for the support of the public crowd, it must gather the public strength, the introduction of social capital to participate in sponge city construction and management, while the strength of enterprises involved in technology research and promotion, timely publicity and construction experience and achieved the results.

\section{Conclusion}

At present, with the development of social economy, the number of rainstorms has become more and more frequent, leading to the construction of rainwater system in many cities such as coastal areas. This paper mainly analyzes the establishment of sponge city, mainly from the rainwater absorption, rainwater storage, water seepage and water purification and other aspects of the comprehensive utilization of rainwater, to achieve the coordinated development of urban ecological resources, enhance the urban flood control capacity, improve the urban construction quality and create a harmonious atmosphere of harmony between man and nature.

\section{References:}

[1] Xie Qiuhao. Research on the Sustainable Development Idea of Sponge City Construction [J]. Doors and Windows, 2016, (06).

[2] Lin Chuantong. The Application of Sponge's City Idea in Urban Road Construction $[\mathrm{J}]$. Building materials, 2016, (21).

[3] Zhang Hua. The Influence of Sponge's City Idea on Urban Planning and Construction [J]. Architectural Knowledge, 2016, (06).

[4] Wang Weili. Construction Strategy of Livable City Based on Sponge's City Idea [J]. Chinese and foreign architecture, 2016, (11). 